\title{
Effect of Lime and Phosphorus Fertilizer on Soybean [Glycine $\max$ L. (Merrill)] Grain Yield and Yield Components at Mettu in South Western Ethiopia
}

\author{
Tolossa Ameyu*, Efrem Asfaw \\ Ethiopian Institute of Agricultural Research, Jimma Agricultural Research Center, Jimma, Ethiopia
}

Email address:

tolamboo@gmail.com(T. Ameyu)

${ }^{*}$ Corresponding author

\section{To cite this article:}

Tolossa Ameyu, Efrem Asfaw. Effect of Lime and Phosphorus Fertilizer on Soybean [Glycine max L. (Merrill)] Grain Yield and Yield Components at Mettu in South Western Ethiopia. International Journal of Environmental Monitoring and Analysis.

Vol. 8, No. 5, 2020, pp. 144-154. doi: 10.11648/j.ijema.20200805.13

Received: June 8, 2020; Accepted: June 22, 2020; Published: September 24, 2020

\begin{abstract}
Soil acidity and poor soil fertility are regarded as crop productivity limiting factors particularly in south western Ethiopia. Acidic soils limit the productive potential of crops because of low availability of basic cations and excess of hydrogen and aluminium in exchangeable forms. At the study area, soil acidity is a well-known problem limiting crop productivity. This, study was conducted to determine the effect of lime and phosphorus fertilizers on soybean yields and to explore the best treatments that can maximize the productivity of soybean. Factorial combinations of five lime levels $(0,1.41$, 2.82, 4.23 and $\left.5.64 \mathrm{t} \mathrm{ha}^{-1}\right)$ and four P levels $\left(0,10,20\right.$ and 30 $\left.\mathrm{kg} \mathrm{P} \mathrm{ha}^{-1}\right)$ were laid out in Randomized Complete Block Design (RCBD) with three replications. Data on yield and yield components, were collected and analyzed using SAS version 9.3 software. Treatment means were compared at 5\% level of significance using List Significant Different Test. The results revealed that Lime $\mathrm{x}$ phosphorus interactions were significant $(\mathrm{p}<0.01)$ for some yield and yield components. Findings showed that the application of phosphorus $(30 \mathrm{Kg} / \mathrm{ha})$ significantly increased the plant height $(67.03 \mathrm{~cm})$, number of pods per plant (49), number of seeds per plant (77.67) above ground biomass $(6160 \mathrm{Kg} / \mathrm{ha})$ and the grain yield $(1828.44 \mathrm{Kg} / \mathrm{ha})$. A combined application of phosphorous at $30 \mathrm{~kg} / \mathrm{ha}$ and lime at $5.64 \mathrm{t} \mathrm{ha}^{-1}$ had good response in reclaiming the soil and fostering the crop productivity, which is statically at pars with $4.23 \mathrm{lime} \mathrm{t} / \mathrm{ha}$ and $30 \mathrm{P} \mathrm{kg} / \mathrm{ha}$. Study concluded that application of lime with phosphorus proved to be superior with respect to grain yield as well as other yield and growth parameters of soybean. The result of this study verified that application of lime and Phosphorus improved yield and yield related traits of soybean crop. In conclusion further study should be conducted to determine the response of different maturity group of soybean varieties to appropriate rates or combination of lime and phosphorus fertilizers which can maximize the productivity of the crop and reduce soil acidity problem in the study area and finally, the study should be conducted across different acid soil and the agricultural extension suggest the farmers as they apply lime based on the concentration of acid saturation cation until the best combination of lime and phosphorus will be determined.
\end{abstract}

Keywords: Lime, Phosphorus, Soil Acidity and Soybean

\section{Introduction}

Soil acidity has become a grave challenge to agricultural production around the world and for developing countries in particular. Soil acidification is a complex set of processes resulting into the formation of acidic soils. The accumulation of different anthropogenic and natural processes viz leaching of exchangeable bases, basic cation (calcium, magnesium and potassium) uptake by plants, decomposition of organic materials, application of chemical fertilizers and other farming practices turning soils into acidic [4]. Climate, vegetation and parent material are the soil forming factors likely to upsurge soil acidity in Ethiopia [18]. Area affected by acidity is estimated at 4 billion ha, representing about 
$30 \%$ of the total ice-free land area of the world [22]. Acidic soils are widely distributed in developing countries, where population escalation is gradual and demand for food is growing.

In Ethiopia, of the total land, about $41 \%$ is affected by the soil acidity. Of the acidic soil, about $28 \%$ is moderate to weak acidic ( $\mathrm{pH}$ in $\mathrm{KCl}$ of $4.5-5.5)$, and $13.2 \%$ is highly acidic ( $\mathrm{pH}$ in $\mathrm{KCl}$ of $<4.5$ ). Ethiosis [7] had estimated about $43 \%$ of the Ethiopian arable land had turned acidic..

Soybean is appealing crop for livestock in the form of forage (as hay and silage) or soybean meal. Soybean has wide adaptability coupled with its higher productivity potential as compared to other grain legumes. In Ethiopia, pulses rank second as food crops after cereals, occupying $17.7 \%$ of the total cultivated area, and contribute $12 \%$ of the total crop production. Soybean is one of the most important pulse crops of the country with an annual production of 7,205 tons in 2009. Subsistence farmers in different parts of the country, who have been engaged in soybean production, are benefiting from the multiple uses of the crop. The productivity of soybean on farmer's field has been very low i.e., $920-1410 \mathrm{~kg} \mathrm{ha}^{-1}$ relative to its potential productivity 2000-3500 $\mathrm{kg} \mathrm{ha}^{-1}$. The low productivity has been attributed to several constraints among which include: lack of application of the right type and amount of fertilizers and poor soil fertility / acidity management are the major once. Currently, there are also factories producing oil from soybean showing increasing importance of soybean in the country. It also counter effects depletion of plant nutrients especially nitrogen in the soil resulting from continuous mono-cropping of cereals, especially maize and sorghum, thereby contributing to increasing soil fertility.

Increased soil acidity causes solubilization of $\mathrm{Al}^{3+}$, which is the primary source of toxicity to plants at $\mathrm{pH}$ below 5.5, and deficiencies of $\mathrm{P}, \mathrm{Ca}, \mathrm{Mg}, \mathrm{N}, \mathrm{K}$ and micronutrients [10; 18]. Among these constraints, $\mathrm{Al}$ toxicity and $\mathrm{P}$ deficiency are the most important ones, due to their ubiquitous existence and overwhelming impact on plant growth [13], which limits crop growth and development that adversely affects crop production. For crop production, soil acidity is a complex of numerous factors involving nutrient deficiencies and toxicities, low activities of beneficial micro organisms, and reduced plant root growth, which limits absorption of nutrients and water [8]. For these reasons some farmers use locally available liming materials like coffee husk, organic source of liming etc, however such liming material doesn't work as that of $\mathrm{CaCO} 3$ because of slowly releasing nutrients.

However, $\mathrm{Al}^{3+}$ toxicity is one of the major limiting factors for soybean production on acid soils by inhibiting root cell division and elongation, thereby, reducing water and nutrient uptake, poor nodulation or mycorrhizal infections [6], consequently leading to poor growth of soybean and its yields. Such problematic soils require careful soil fertility management practices to enhance soybean production and productivity, most specifically application of agricultural lime. Limes are materials containing carbonates, oxides or hydroxides that are important to amend soil acidity to raise soil $\mathrm{pH}$ and neutralize toxic elements in the soil. Studies have shown that apart from reducing the acidity of the soil by counteracting the effects of excess $\mathrm{H}^{+}$and $\mathrm{Al}^{3+}$ ions, liming also has several other benefits including, its ability to reduce the toxicity effects of some micro elements by lowering their concentrations; increasing the availability of plant nutrients, such as $\mathrm{Ca}, \mathrm{P}, \mathrm{Mo}$, and $\mathrm{Mg}$ in the soil, and reducing the solubility and leaching of heavy metals [8].

Phosphorus is known as the master key to agriculture and lack of available $\mathrm{P}$ nutrient in the soil limits the growth of both cultivated and uncultivated plants [9]. It is the second most important macronutrient next to nitrogen in limiting crop growth. Despite its importance in plants growth and metabolism, phosphorus is the least accessible macronutrient and hence most frequently deficient nutrient in most agricultural soils because of its low availability and its poor recovery from the applied fertilizers. The low availability of phosphorus is due to the fact that it readily forms insoluble complexes with cation such as aluminum and iron under acidic soil condition whereas the poor $\mathrm{P}$ fertilizer recovery is due to the fact that the $\mathrm{P}$ applied in the form of fertilizers is mainly adsorbed by the soil, and is not available for plants lacking specific adaptations.

At western, southern and central highlands of Ethiopia low availability of $P$ under most soils is due to the impacts of $P$ fixation by acidic cations, abundant loss of $\mathrm{P}$ by crop harvest and erosion and the inherent $\mathrm{P}$ deficiency of the soils by little or no P sourced fertilizers application [16]. Hence, liming and $\mathrm{P}$ fertilization appears to be amongst the most important operations required to boost soybean productivity in Ethiopia. However, there are no or little research results available in literature on the effect of lime and $P$ fertilizer in soybean production in Ethiopia. Therefore, the objectives of the study were: to assess the effect of lime and phosphorus fertilizer application on yield and yield components of soybean at Mettu and, to investigate the interactive effects of lime and $\mathrm{P}$ fertilizer on soybean grain yield, yield components and some soil chemical properties under acid soil condition in Mettu South Western Ethiopia.

\section{Materials and Methods}

\subsection{Description of the Study Site}

The study was carried out at Mettu Agricultural Research Sub Center of Jimma Agricultural Research Center, under the Ethiopian Institute of Agricultural Research (EIAR) during main cropping season. The sub-center is located at $600 \mathrm{~km}$ away from Addis Ababa in Iluabbabora Zone of the Oromia Regional National State. Geographically, it is located at latitude $8^{\circ} 19^{\prime} 0^{\prime \prime} \mathrm{N}$ longitude $35^{\circ} 35^{\prime} 0^{\prime \prime} \mathrm{E}$ at an altitude of 1550 m.a.s.l. Agro-climatically, it has been characterized as Tepid (slightly warm) to cool humid mid highlands with annual rainfall distribution pattern of $1835 \mathrm{~mm} /$ annum. The mean annual temperature ranges from 12 to $27^{\circ} \mathrm{C}$. The predominant soil type is Nitisol, which is dark red brown, and characterized by very strong to moderately acidic soil, 
and low soil $\mathrm{P}$, specifically around experimental sites with $\mathrm{pH}$ of 4.5, and phosphorus level of $1.16 \mathrm{ppm}$ and exchangeable acidity of $2.48 \mathrm{meq} / 100 \mathrm{~g}$ of soil.

\subsection{Treatments and Experimental Design}

The treatments comprised of two factors namely; five levels of lime $(0.0 \mathrm{x}, 0.5 \mathrm{x}, 1.0 \mathrm{x}, 1.5 \mathrm{x}$ and $2.0 \mathrm{x}$, exchangeable $\mathrm{Al}^{+3}$ and $\mathrm{H}^{+1}$ ) with corresponding lime rate of $0,1.41,2.82$, 4.23 , and 5.64 tons $\mathrm{ha}^{-}{ }^{1}$ and four rate of phosphorus $(0,23$, 46 and $69 \mathrm{~kg}$ P2O5 ha $\left.{ }^{-1}\right)$ or $(0,10,20$ and $30 \mathrm{~kg} \mathrm{P} / \mathrm{ha})$. The treatments were laid out in a randomized complete block design with three replications.
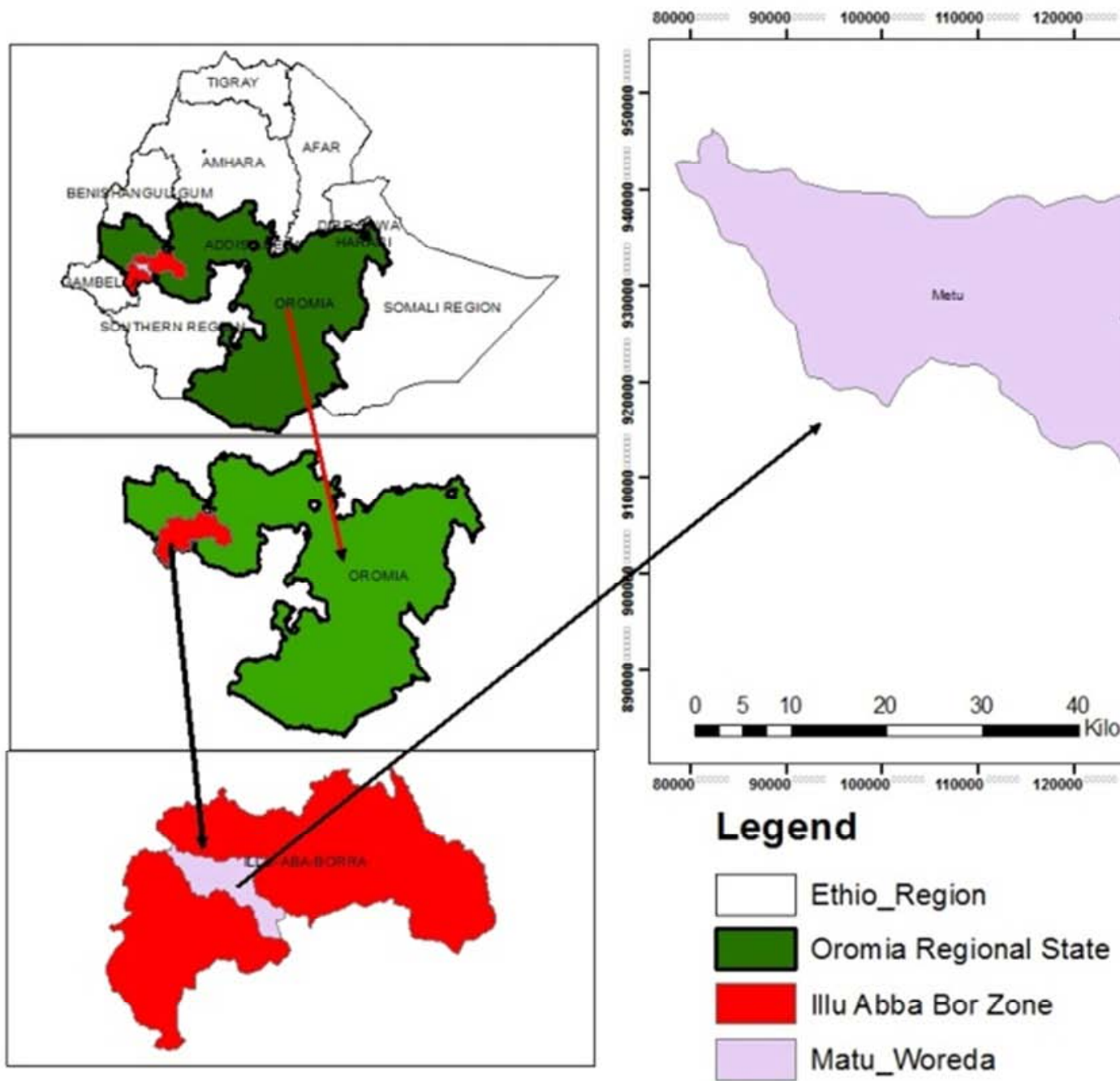

Figure 1. Location Map of the study area.

\subsection{Experimental Procedure}

The study was conducted on soybean during 2015/16 cropping seasons in Iluabbabora zones at Mettu research subcenter. Prior to the commencement of the trial, composite soil samples were collected from the upper $20 \mathrm{~cm}$ depth and analysed for soil $\mathrm{pH}$ and exchangeable acidity. The amounts of lime applied was determined based on the exchangeable acidity, mass per $0.15 \mathrm{~m}$ furrow slice and bulk density of the soil [21], considering the amount of lime needed to neutralize the acid content $(\mathrm{Al}+\mathrm{H})$ of the soil up to the permissible acid saturation level for soybean growth as described in equation below.

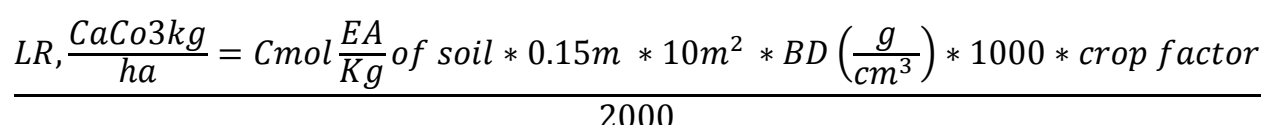

Where: $\mathrm{BD}=$ bulk density, EA =exchangeable acidity (exch. $\mathrm{H}^{+}+\mathrm{Al}^{3+}$ ), LR=lime requirements, $0.15 \mathrm{~m}=$ plough $\mathrm{depth} /$ depth of lime incorporation. Crop factor $=1.5$

$2000=$ to convert exchangeable acidity per $\mathrm{kg}$ of soil to per hectare
Soybean variety Clarck 63 as used as a test crop, because of this variety was selected for the study area previously by breeder. Calcium carbonate was used as the source of lime and the whole doses of lime of the respective treatment were broadcasted uniformly by hand and mixed in the top $15 \mathrm{~cm}$ 
soil layer, a month before sowing, to mix lime with soil properly. Phosphorus fertilizer recommended ( $46 \mathrm{~kg} \mathrm{P}_{2} \mathrm{O}_{5}$ ha ${ }^{1}$ from Triple Super Phosphate) was applied at planting and mixed with the soil based on the rate of treatments, while the recommended $\mathrm{N}$ rate $\left(46 \mathrm{~kg} \mathrm{~N} \mathrm{ha}^{-1}\right)$ was applied uniformly to all experimental plots as urea in two split; half at seed sowing and the remaining half when the seedlings attained one month after sowing.

Soybean seeds were planted on mid June as per the recommended soybean planting period. Two seeds were sown in rows per hill to maintain between plants and rows spacings of 5 and $60 \mathrm{~cm}$, respectively and then thinned to one plant after seedling establishment. The size of each plot was $4 \mathrm{~m} * 4 \mathrm{~m}=16 \mathrm{~m}^{2}$ and the spacing between replication and plots were 1.5 and $1 \mathrm{~m}$, respectively. All the recommended cultural practices were used for the management of the experimental crop uniformly.

\subsection{Soil Sampling, Preparation and Analysis Before Planting and After Harvesting}

Prior to the field experimentation both undisturbed and disturbed samples were collected. Three undisturbed samples were taken by core sampler. Fresh weight and an oven dry weight at $105^{\circ} \mathrm{C}$, and used to determine bulk density [2]. Ten random disturbed composite soil samples $(0-15 \mathrm{~cm}$ depth) were collected and a composite soil sample was made. The composite sample was used for soil chemical analysis, and for the determination of lime requirement of the soil. The disturbed soil samples were air dried, sieved to pass through 2 $\mathrm{mm}$ sieve, and placed in a labeled plastic bag and transported to Jimma Agricultural Research Center soil laboratory for analysis i.e. soil exchangeable acidity $\left(\mathrm{Al}^{3+}\right.$ and $\left.\mathrm{H}^{+}\right)$and soil $\mathrm{pH}$. After harvesting, the soil samples were collected individual plot-wise from each replication from the surface 0$15 \mathrm{~cm}$ depth for soil exchangeable acidity $\left(\mathrm{Al}^{3+}\right.$ and $\left.\mathrm{H}^{+}\right)$and soil pH analysis. Finally, yield and yield components, and soil data were subjected to analysis of variance using SAS statistical software [19]. LSD was used to separate significantly differing treatment means after treatment effects were found significant at $\mathrm{P} \leq 0.05$.

\section{Results and Discussion}

\subsection{Effect of Lime and Phosphorus on Soil Chemical Properties (Exchangeable Acidity and pH) After Harvesting}

Soil $\mathrm{pH}$ and exchangeable acidity $\left(\mathrm{Al}^{3+}\right.$ and $\left.\mathrm{H}^{+}\right)$were significantly $(\mathrm{P}=0.05)$ influenced by the main effects of lime (Figures 1 \& 2). Lime interacted with phosphorus and main effect of phosphorus non-significant on soil $\mathrm{pH}$ and exchangeable acidity $\left(\mathrm{Al}^{3+}\right.$ and $\left.\mathrm{H}^{+}\right)$. Application of lime alone showed the change in soil $\mathrm{pH}$. This indicated that when lime is added to acid soils that contain high $\mathrm{Al}^{3+}$ and $\mathrm{H}^{+}$ concentrations, it dissociates into $\mathrm{Ca}^{2+}$ and $\mathrm{OH}^{-}$ions. The hydroxyl ions will react with hydrogen and $\mathrm{Al}^{3+}$ ions forming $\mathrm{Al}^{3+}$ hydroxide and water; thereby, increasing soil $\mathrm{pH}$ in the soil solution. Increase in the soil $\mathrm{pH}$ over the control, in response to the application of lime alone or combined with $\mathrm{P}$ was reported by [23]. [16] Also reported that the application of $0.4 \mathrm{tha}^{-1}$ lime increased soil $\mathrm{pH}$ by $7 \%$, relative to unlimed control. The present findings are also in agreement with [26] who reported that application of lime at the rate of $2 \mathrm{t}$ ha- ${ }^{1}$ significantly increased top soil $\mathrm{pH}$ values from 4.6 to 6.0 . Exchangeable acidity of the soil was also decreased in response to the application of lime (Figure 2). Application of lime reduced soil exchangeable acidity due to increased replacement of $\mathrm{Al}$ by $\mathrm{Ca}$ in the exchange site and subsequent precipitation of $\mathrm{Al}$, as $\mathrm{Al}(\mathrm{OH})_{3}$, due to liming of the soil [8].

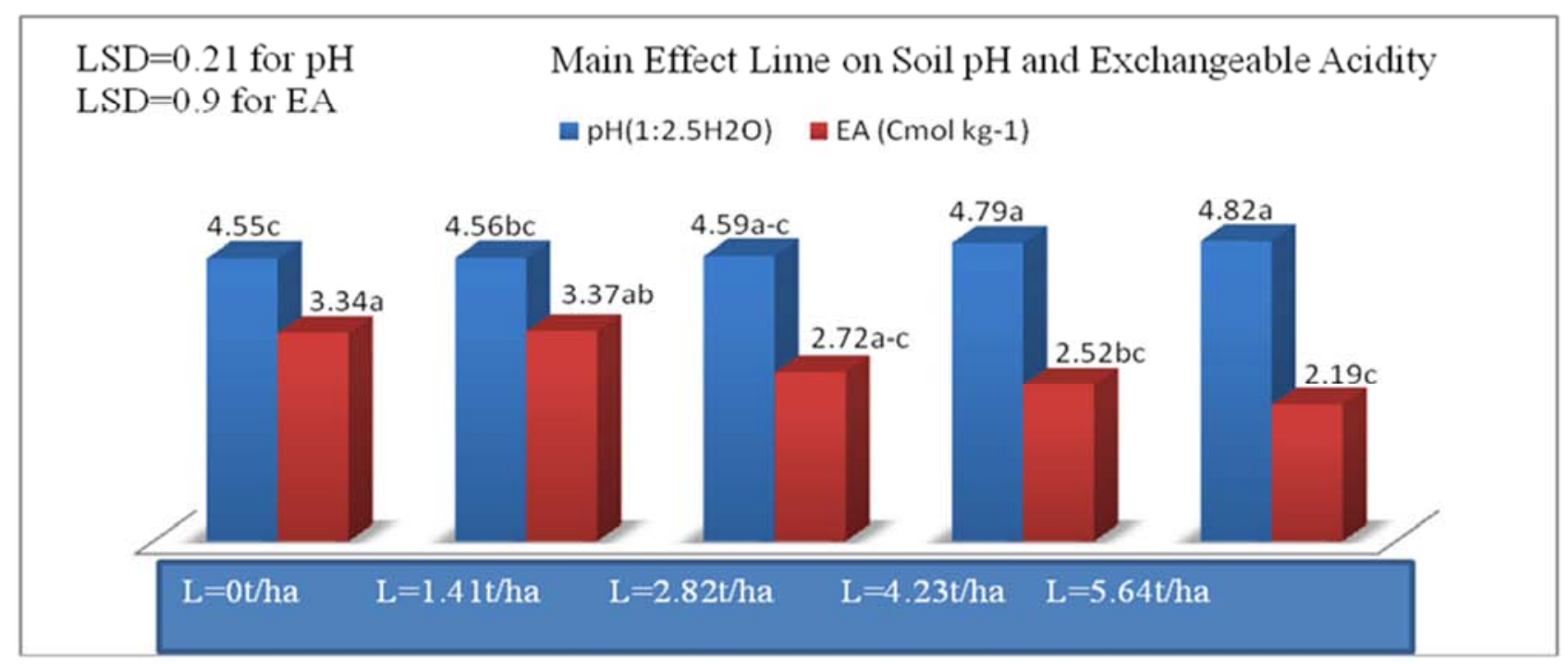

Figure 2. Effect of lime on soil exchangeable acidity and $p H$ at Mettu.

Means with the same letter(s) are statistically not significantly different at 0.05 probability level

Where, $\mathrm{L}=$ lime, $\mathrm{LSD}=$ list significant different, $\mathrm{EA}=$ Exchangeable acidity, $\mathrm{t}=\mathrm{ton}$ 


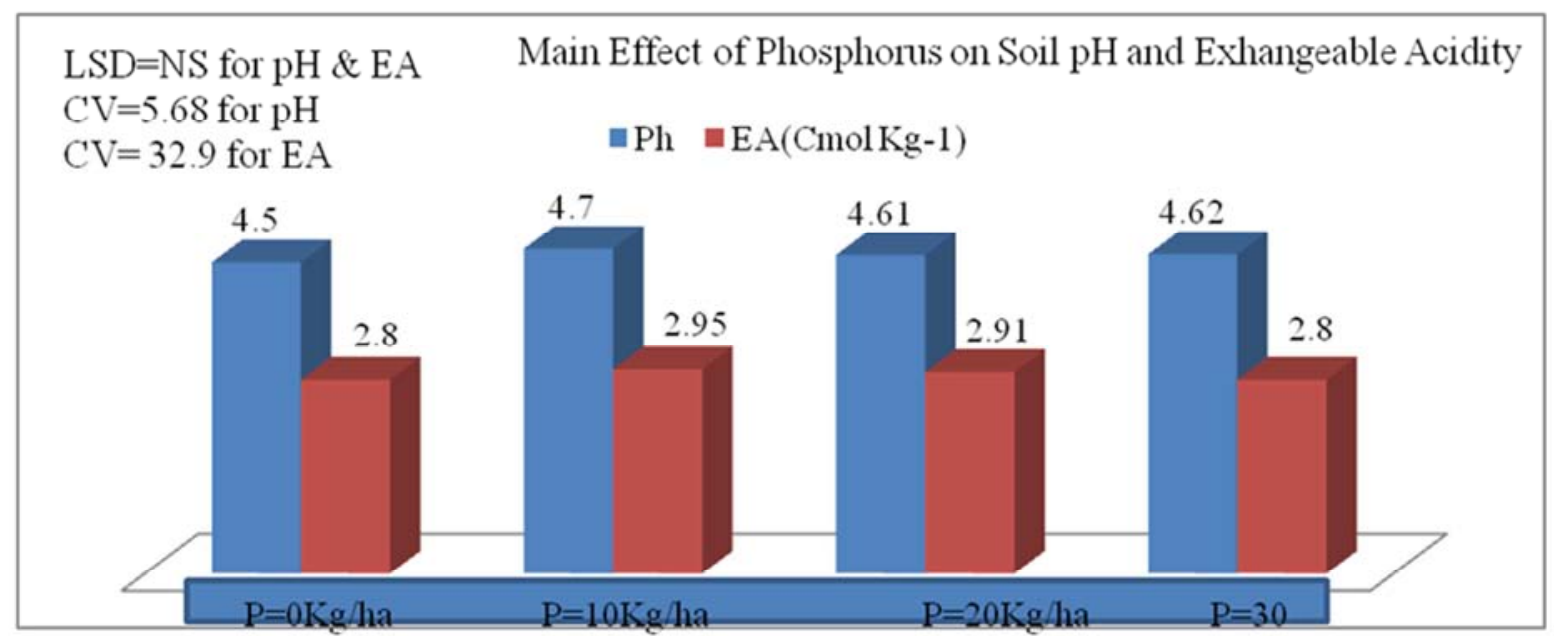

$\mathrm{Kg} / \mathrm{ha}$

Where, $\mathrm{P}=$ phosphorus, $\mathrm{LSD}=$ list significant different, $\mathrm{EA}=$ Exchangeable acidity, $\mathrm{Kg} / \mathrm{ha}=\mathrm{kilogram}$ per hectare, $\mathrm{NS}=$ non significant different

Figure 3. Effect of Phosphorus on soil exchangeable acidity and $p H$ at Mettu.

\subsection{Effect of Lime and Phosphorus on Soybean Plant Height and Number of Pod Per Plant}

The main effect of lime, season and phosphorus had a significantly influence on plant height (Figures 4 and 5). Similarly, the interaction effect of phosphorus $\mathrm{x}$ season $\mathrm{x}$ lime showed significant effect on plant height (Table 1). Among various phosphorus levels, the longest plant height $(67.03 \mathrm{~cm})$ was recorded at the rate of $30 \mathrm{~kg} \mathrm{P} \mathrm{ha}^{-1}$ while the shortest plant height $(44.52 \mathrm{~cm})$ was recorded at $0 \mathrm{~kg} \mathrm{P}$ ha${ }^{1}$ (Figure 5). Significant increase in plant height was attained with lime application (Figure 4). Application of lime significantly improved plant height of soybean over unlimed soil where the longest plant height $(59.95 \mathrm{~cm})$ was recorded with liming at $5.64 \mathrm{t} /$ ha while the shortest plant height $(56.5$ $\mathrm{cm})$ was recorded from unlimed soil (0t/ha) (Figure 4). The results in Table 1 showed significant interaction between lime rate and phosphorus levels on plant height. The shortest plant height $(39.8 \mathrm{~cm})$ was recorded in control treatments $(0$ $\mathrm{kg} \mathrm{P} \mathrm{ha}{ }^{-1}$ and $0 \mathrm{t} /$ ha lime) whereas the tallest plant height $(74.4 \mathrm{~cm})$ was recorded at the rate of $30 \mathrm{~kg} \mathrm{P} \mathrm{ha}^{-1}$ and limed at the rate of $4.23 \mathrm{t} /$ ha (Table 1 ).

This positive growth response of soybean for application of phosphorus and lime in acidic soil may be due to the effect of liming that neutralized soil acidity, which in turn might have improved the availability of plant nutrients, particularly phosphorus and calcium and lowered the concentration of toxic cations, mainly $\mathrm{Al}^{3+}$ ions. This in turn, improves plant growth, most likely resulted from the enhanced conditions for seedling growth. The application of $\mathrm{P}$ fertilizer together with lime amendment has a very important role (Table 1), which might increase the availability of applied $\mathrm{P}$, and also helps in raising $\mathrm{pH}$ of the soil and reduce the effect of acidity on the performance of the crop. However, phosphorous deficiency causes immediate disturbances in metabolism and suffered to stunted growth. This positive growth response of soybean for application of $\mathrm{P}$ in acidic soil may be related with better availability of $\mathrm{P}$ as the rate of $\mathrm{P}$ application increased. The significant increase in soybean growth after lime application can also be attributed to reduced aluminium toxicity which inhibit root growth by reducing cell elongation and cell division hence reduced main axis and lateral root formation. The results are similar with the results of [12] who reported that a growth of plant is increased on acid soil in response to the application of $\mathrm{P}$ with lime. Tigist, (2017) reported $36.4 \%$ plant height decrease in soybean on unlimed acid soil compared with limed acid soil.

Table 1. Interaction effect of lime, season and phosphorus on plant height of soybean at Mettu.

\begin{tabular}{|c|c|c|c|c|c|}
\hline \multirow{3}{*}{ Lime rate } & \multicolumn{5}{|c|}{ Plant height (cm) } \\
\hline & \multirow{2}{*}{ Year } & \multicolumn{4}{|c|}{ Phosphorus level } \\
\hline & & $0 \mathrm{~kg} / \mathrm{ha}$ & $10 \mathrm{~kg} / \mathrm{ha}$ & $20 \mathrm{~kg} / \mathrm{ha}$ & $30 \mathrm{~kg} / \mathrm{ha}$ \\
\hline \multirow[t]{3}{*}{$0 \mathrm{t} / \mathrm{ha}$} & 2013 & $41.00^{\mathrm{CD}}$ & $50.57^{\mathrm{x}-\mathrm{zA}}$ & $65.90^{\mathrm{d}-\mathrm{n}}$ & $61.50^{\mathrm{h}-\mathrm{u}}$ \\
\hline & 2014 & $42.00^{\mathrm{B}-\mathrm{D}}$ & $54.93^{t-x}$ & $57.67^{\mathrm{r}-\mathrm{w}}$ & $61.93^{\mathrm{g}-\mathrm{t}}$ \\
\hline & 2015 & $39.80^{\mathrm{D}}$ & $56.93^{t-x}$ & $63.57^{\mathrm{e}-\mathrm{t}}$ & $71.73^{\mathrm{a}-\mathrm{d}}$ \\
\hline \multirow[t]{2}{*}{$1.41 \mathrm{t} / \mathrm{ha}$} & 2013 & $42.57^{\mathrm{B}-\mathrm{D}}$ & $61.13^{j-v}$ & $69.00^{\mathrm{a}-\mathrm{f}}$ & $66.40^{\mathrm{d}-\mathrm{m}}$ \\
\hline & 2014 & $42.87^{\mathrm{B}-\mathrm{D}}$ & $53.37^{\mathrm{w}-\mathrm{z}}$ & $59.80^{1-w}$ & $60.40^{\mathrm{j}-\mathrm{v}}$ \\
\hline \multirow[t]{3}{*}{$2.82 \mathrm{t} / \mathrm{ha}$} & 2013 & $45.17^{\mathrm{A}-\mathrm{D}}$ & $58.76^{\mathrm{p}-\mathrm{w}}$ & $68.53^{\mathrm{a}-\mathrm{g}}$ & $66.70^{\mathrm{c}-\mathrm{k}}$ \\
\hline & 2014 & $47.40^{\mathrm{zA}-\mathrm{C}}$ & $54.40^{\mathrm{v}-\mathrm{y}}$ & $57.73^{\mathrm{r}-\mathrm{w}}$ & $63.73^{\mathrm{e}-\mathrm{s}}$ \\
\hline & 2015 & $45.33^{\mathrm{A}-\mathrm{D}}$ & $61.13^{\mathrm{i}-\mathrm{v}}$ & $68.77^{\mathrm{a}-\mathrm{g}}$ & $74.40^{\mathrm{a}}$ \\
\hline \multirow[t]{2}{*}{$4.23 \mathrm{t} / \mathrm{ha}$} & 2013 & $46.13^{\mathrm{A}-\mathrm{D}}$ & $57.03^{\mathrm{s}-\mathrm{x}}$ & $67.03^{b-j}$ & $67.33^{\mathrm{b}-\mathrm{i}}$ \\
\hline & 2014 & $46.80^{\mathrm{ZA}-\mathrm{C}}$ & $57.20^{r-x}$ & $59.53^{\mathrm{n}-\mathrm{w}}$ & $62.33^{\mathrm{f}-\mathrm{t}}$ \\
\hline
\end{tabular}




\begin{tabular}{|c|c|c|c|c|c|}
\hline \multirow{3}{*}{ Lime rate } & \multicolumn{5}{|c|}{ Plant height (cm) } \\
\hline & \multirow{2}{*}{ Year } & \multicolumn{4}{|c|}{$\begin{array}{l}\text { Phosphorus level } \\
\end{array}$} \\
\hline & & 0kg/ha & $10 \mathrm{~kg} / \mathrm{ha}$ & $20 \mathrm{~kg} / \mathrm{ha}$ & $30 \mathrm{~kg} / \mathrm{ha}$ \\
\hline \multirow{4}{*}{$5.64 \mathrm{t} / \mathrm{ha}$} & 2015 & $44.33^{\mathrm{A}-\mathrm{D}}$ & $59.00^{p-w}$ & $63.93^{\mathrm{e}-\mathrm{q}}$ & $73.77^{\mathrm{abc}}$ \\
\hline & 2013 & $47.33^{\mathrm{zA}-\mathrm{C}}$ & $59.73^{\mathrm{n}-\mathrm{w}}$ & $64.60^{e-q}$ & $66.67^{\mathrm{c}-1}$ \\
\hline & 2014 & $46.73^{\mathrm{ZA}-\mathrm{C}}$ & $58.00^{\mathrm{q}-\mathrm{w}}$ & $62.20^{\mathrm{g}-\mathrm{t}}$ & $65.80^{\mathrm{d}-\mathrm{o}}$ \\
\hline & 2015 & $48.13^{\mathrm{yzAB}}$ & $59.067^{0-\mathrm{w}}$ & $67.93^{\mathrm{a}-\mathrm{h}}$ & $73.37^{\mathrm{abc}}$ \\
\hline Mean & 58.26 & & & & \\
\hline $\mathrm{CV}$ & 7.19 & & & & \\
\hline LSD & 6.77 & & & & \\
\hline
\end{tabular}

Means with capital letters are the letters come backs after Z. Means with the same letter(s) are statistically not significantly different at 0.05 probability level. Where, $\mathrm{t} / \mathrm{ha}=$ ton per hectare, $\mathrm{LSD}=$ list significant different, $\mathrm{CV}=$ coefficient of variation

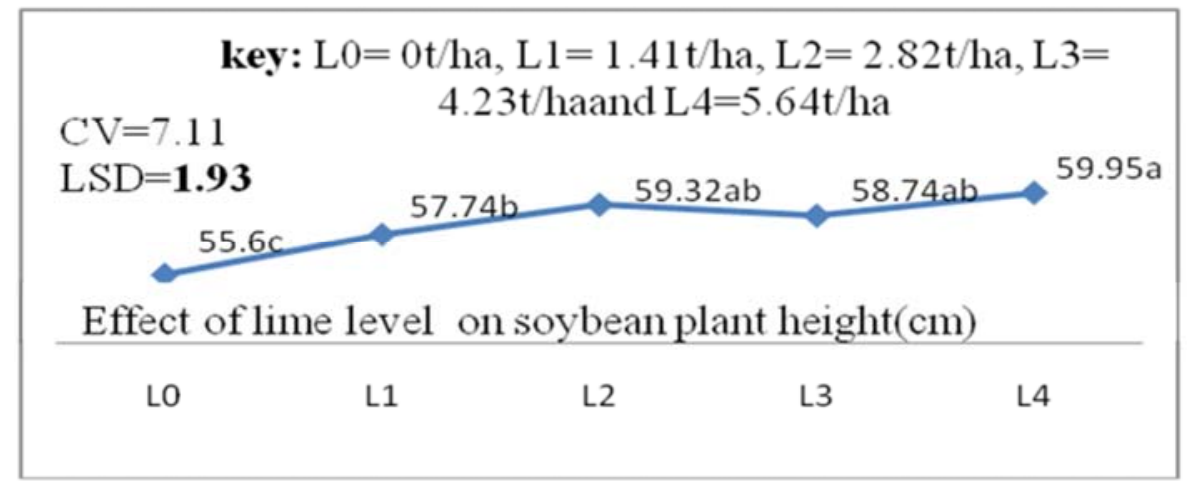

Figure 4. Main Effect of Lime on Soybean Plant Height at Mettu.

Means with the same letter(s) are statistically not significantly different at 0.05 probability level Where, $\mathrm{L}=$ lime, $\mathrm{LSD}=$ list significant different, $\mathrm{CV}=$ coefficient of variation

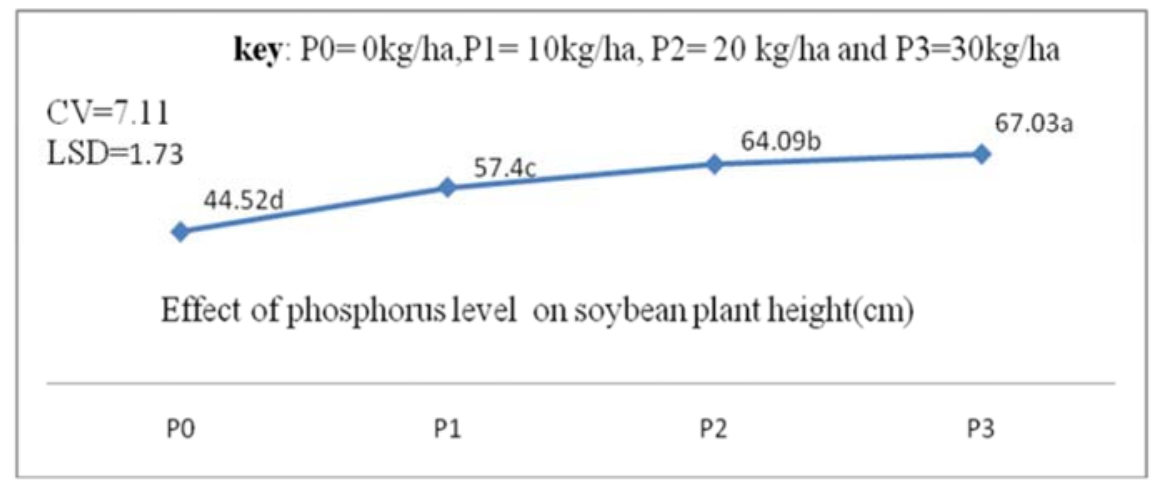

Figure 5. Figure 4 Main Effect of Phosphorus on Soybean Plant Height at Mettu.

Means with the same letter(s) are statistically not significantly different at 0.05 probability level

Where, $\mathrm{P}=$ phosphorus, $\mathrm{LSD}=$ list significant different, $\mathrm{CV}=$ coefficient of variation

Analysis of variance showed that the main effects of lime, season and phosphorus, and interaction of phosphorus $\mathrm{x}$ season $\mathrm{x}$ lime had highly significant $(\mathrm{P}<0.01)$ effect on number of pods per plant (Table 2). The results in Table 2 showed significant interaction between lime and phosphorus levels on number of pods per plant. The lowest number of pods per plant (15.33) was recorded in control treatment $(0$ $\mathrm{kg} \mathrm{P} \mathrm{ha}{ }^{-1}+0 \mathrm{t} /$ ha lime) whereas the highest number of pods per plant (49) was recorded at the rate of $20 \mathrm{~kg} \mathrm{P} \mathrm{ha}^{-1}+$ 4.23t/ha lime treatments (Table 2).

The applied lime and P improved number of pod per plant, which might be due to lime and phosphorus enhanced vegetative growth, thereby, enabling the plant to bear higher number of pods than the untreated soil condition, and neutralizing soil acidity by lime, which in turn increases availability of $\mathrm{P}$ for plant uptake, through reduction in its fixation on acid soils as well as increases calcium availability in the soil [12]. [23] Reported that the application of lime with P significantly increased number of pods per plant for soybeans. [26] Also reported that combined application of lime and phosphorus produced the highest pods per plant than their separate application. Liming enhances $P$ uptake by alleviating Al toxicity and thereby improving root growth and the improved root growth would allow a great volume of soils to be explored finally this in turn favors the improvement of soybean yield components i.e. pod per plant. 
Table 2. Interaction effect of lime, season and phosphorus level on number of pod per plant of soybean at Mettu.

\begin{tabular}{|c|c|c|c|c|c|}
\hline \multirow{3}{*}{ Lime rate } & \multicolumn{5}{|c|}{ Number of pod per plant in number } \\
\hline & \multirow{2}{*}{ Year (GC) } & \multicolumn{4}{|c|}{ Phosphorus level (kg/ha) } \\
\hline & & 0kg/ha & $10 \mathrm{~kg} / \mathrm{ha}$ & $20 \mathrm{~kg} / \mathrm{ha}$ & $30 \mathrm{~kg} / \mathrm{ha}$ \\
\hline \multirow[t]{3}{*}{$0 \mathrm{t} / \mathrm{ha}$} & 2013 & $20.00^{r-w}$ & $35.77^{\mathrm{c}-1}$ & $37.33^{b-j}$ & $31.33^{i-q}$ \\
\hline & 2014 & $25.77^{\mathrm{m}-\mathrm{u}}$ & $32.33^{\mathrm{g}-\mathrm{p}}$ & $39.33^{a-i}$ & $41.33^{\mathrm{a}-\mathrm{h}}$ \\
\hline & 2015 & $15.33^{\mathrm{w}}$ & $25.00^{\mathrm{o}-\mathrm{w}}$ & $28.33^{\mathrm{j}-\mathrm{r}}$ & $32.00^{h-p}$ \\
\hline \multirow[t]{3}{*}{$1.41 \mathrm{t} / \mathrm{ha}$} & 2013 & $20.33^{r-w}$ & $37.77^{\mathrm{b}-\mathrm{j}}$ & $42.33^{\mathrm{a}-\mathrm{f}}$ & $45.00^{\mathrm{abc}}$ \\
\hline & 2014 & $25.00^{0-w}$ & $35.77^{\mathrm{c}-1}$ & $42.0^{\mathrm{a}-\mathrm{g}}$ & $44.00^{\mathrm{a}-\mathrm{d}}$ \\
\hline & 2015 & $15.77^{\mathrm{vw}}$ & $23.77^{\mathrm{p}-\mathrm{w}}$ & $33.33^{\mathrm{f}-\mathrm{p}}$ & $35.33^{\mathrm{c}-\mathrm{m}}$ \\
\hline \multirow[t]{3}{*}{$2.82 \mathrm{t} / \mathrm{ha}$} & 2013 & $26.77^{1-\mathrm{s}}$ & $37.77^{\mathrm{b}-\mathrm{j}}$ & $40.00^{\mathrm{a}-\mathrm{i}}$ & $40.33^{a-i}$ \\
\hline & 2014 & $26.33^{1-t}$ & $33.77^{\mathrm{e}-\mathrm{o}}$ & $32.77^{\mathrm{f}-\mathrm{p}}$ & $36.77^{\mathrm{b}-\mathrm{k}}$ \\
\hline & 2015 & $18.33^{\text {s-w }}$ & $28.00^{\mathrm{j}-\mathrm{s}}$ & $31.33^{\mathrm{i}-\mathrm{q}}$ & $35.00^{\mathrm{d}-\mathrm{n}}$ \\
\hline \multirow[t]{3}{*}{$4.23 \mathrm{t} / \mathrm{ha}$} & 2013 & $27.00^{1-\mathrm{s}}$ & $31.33^{\mathrm{i}-q}$ & $49.00^{\mathrm{a}}$ & $46.33^{\mathrm{ab}}$ \\
\hline & 2014 & $28.77^{\mathrm{j}-\mathrm{r}}$ & $43.33^{\mathrm{a}-\mathrm{e}}$ & $41.00^{\mathrm{a}-\mathrm{i}}$ & $37.00^{b-j}$ \\
\hline & 2015 & $16.77^{t-w}$ & $22.00^{\mathrm{q}-\mathrm{w}}$ & $32.33^{g-p}$ & $39.77^{a-i}$ \\
\hline \multirow[t]{3}{*}{$5.64 \mathrm{t} / \mathrm{ha}$} & 2013 & $32.0^{h-p}$ & $38.77^{\mathrm{b}-\mathrm{j}}$ & $40.00^{\mathrm{a}-\mathrm{i}}$ & $40.77^{a-i}$ \\
\hline & 2014 & $25.33^{\mathrm{n}-\mathrm{v}}$ & $31.77^{\mathrm{h}-\mathrm{q}}$ & $41.00^{\mathrm{a}-\mathrm{i}}$ & $40.77^{\mathrm{a}-\mathrm{i}}$ \\
\hline & 2015 & $16.00^{\mathrm{u}-\mathrm{w}}$ & $26.33^{1-t}$ & $35.33^{\mathrm{c}-\mathrm{m}}$ & $38.77^{\mathrm{b}-\mathrm{i}}$ \\
\hline Mean & & & 32.83 & & \\
\hline $\mathrm{CV}$ & & & 18.42 & & \\
\hline LSD & & & 9.77 & & \\
\hline
\end{tabular}

Means with the same letter(s) are statistically not significantly different at 0.05 probability level

Where, $\mathrm{t} / \mathrm{ha}=$ ton per hectare, $\mathrm{LSD}=$ list significant different, $\mathrm{CV}=$ coefficient of variation

\subsection{Effect of Lime and Phosphorus on Soybean Grain Yield and Number of Seed Per Plants}

Analysis of variance revealed that the main effect of phosphorus, season and lime application, and their interactions effect of phosphorus $\mathrm{x}$ season $\mathrm{x}$ lime had a significant influence on grain yield of soybean (Table 3). In this study lime and phosphorus significantly influence grain yield of soybean. A combination of lime and phosphorus fertilizer resulted in higher grain yield than that with lime or $\mathrm{P}$ used independently. The highest grain yield of soybean $\left(2271.9 \mathrm{~kg} \mathrm{ha}^{-1}\right)$ was obtained from plants treated with $4.23 \mathrm{t} / \mathrm{ha}$ lime $+30 \mathrm{P} \mathrm{kg} / \mathrm{ha}$ whereas the lowest grain yield $\left(547.1 \mathrm{~kg} \mathrm{ha}^{-1}\right)$ was recorded from both lime and phosphorus untreated plots $(0 \mathrm{~kg} \mathrm{P} / \mathrm{ha}$ and $0 \mathrm{t} / \mathrm{ha}$ lime $)$. The positive response of soybean to the applied lime and $\mathrm{P}$ might be due to the probability of obtaining the available $\mathrm{P}$ from decomposed $\mathrm{OM}$ by microorganisms, when the $\mathrm{pH}$ value of the soil improved due to liming, which might have resulted in increased grain yield [1]. Liming can reduce availability of micronutrients such as iron $(\mathrm{Fe})$, zinc $(\mathrm{Zn})$, manganese $(\mathrm{Mn})$, or boron (B) and increase the availability of the micronutrient molybdenum (Mo) which are essential for growth of the crop [22]. The observed increase in grain yield with increasing $P$ rate in treatments with no lime application confirmed that $\mathrm{P}$ was limiting factor to soybean growth in this soil. Calcium is a structural component of cell walls and is therefore vital in the formation of new cells; hence the Ca supply through liming in the present study could have had a favorable effect on soybean crop yield in the limed plots. Calcium sometimes improves soil structure and soil stability. This could be due to its effect on organic matter decomposition yielding humus and promotes root activity. The results of the present study are in conformity with the work of Mesfin et al. (2014b) who had reported the highest grain yield $\left(1488.4 \mathrm{~kg} \mathrm{ha}^{-1}\right)$ of common bean from the combination of $30 \mathrm{~kg}$ P2O5 ha ${ }^{-1}$ and $0.4 \mathrm{t}$ lime ha ${ }^{-1}$.

Table 3. Interaction effects of lime, season and phosphorus on grain yield of soybean at Mettu.

\begin{tabular}{|c|c|c|c|c|c|}
\hline \multirow{3}{*}{ Lime rate } & \multicolumn{5}{|c|}{ Grain yield $\mathrm{kg} / \mathrm{ha}$} \\
\hline & \multirow{2}{*}{ Year } & \multicolumn{4}{|c|}{ Phosphorus level } \\
\hline & & $0 \mathrm{~kg} / \mathrm{ha}$ & $10 \mathrm{~kg} / \mathrm{ha}$ & $20 \mathrm{~kg} / \mathrm{ha}$ & $30 \mathrm{~kg} / \mathrm{ha}$ \\
\hline \multirow[t]{3}{*}{$0 \mathrm{t} / \mathrm{ha}$} & 2013 & $602.50^{x y}$ & $1360.5^{\mathrm{m}-\mathrm{r}}$ & $2193.0^{\mathrm{a}-\mathrm{c}}$ & $1698.6^{\mathrm{f}-\mathrm{l}}$ \\
\hline & 2014 & $678.10^{v-y}$ & $1231.1^{\mathrm{q}-\mathrm{t}}$ & $1431.1^{\mathrm{k}-\mathrm{r}}$ & $1529.8^{\mathrm{i}-\mathrm{q}}$ \\
\hline & 2015 & $547.10^{y}$ & $1372.7^{\mathrm{m}-\mathrm{r}}$ & $1480.8^{\mathrm{k}-\mathrm{r}}$ & $1866.9^{\mathrm{c}-\mathrm{i}}$ \\
\hline \multirow[t]{3}{*}{$1.41 \mathrm{t} / \mathrm{ha}$} & 2013 & $714.00^{v-y}$ & $1766.3^{\mathrm{e}-\mathrm{k}}$ & $2107.9^{\mathrm{a}-\mathrm{d}}$ & $2111.5^{\mathrm{a}-\mathrm{d}}$ \\
\hline & 2014 & $942.00^{\mathrm{t}-\mathrm{w}}$ & $1479.2^{\mathrm{k}-\mathrm{r}}$ & $1520.2^{\mathrm{j}-\mathrm{q}}$ & $1487.9^{\mathrm{k}-\mathrm{r}}$ \\
\hline & 2015 & $565.50^{x y}$ & $1384.9^{\mathrm{m}-\mathrm{r}}$ & $1564.2^{\mathrm{h}-\mathrm{q}}$ & $1989.1^{\mathrm{a}-\mathrm{f}}$ \\
\hline \multirow[t]{3}{*}{$2.82 \mathrm{t} / \mathrm{ha}$} & 2013 & $1183.0^{\mathrm{r}-\mathrm{u}}$ & $1592.4^{\mathrm{g}-\mathrm{p}}$ & $2251.6^{\mathrm{ab}}$ & $2078.7^{\mathrm{a}-\mathrm{e}}$ \\
\hline & 2014 & $986.80^{\mathrm{s-v}}$ & $1244.0^{\mathrm{q}-\mathrm{t}}$ & $1600.4^{\mathrm{g}-\mathrm{o}}$ & $1659.4^{\mathrm{f}-\mathrm{m}}$ \\
\hline & 2015 & $690.70^{v-y}$ & $1289.6^{\mathrm{o-s}}$ & $1617.7^{\mathrm{g}-\mathrm{o}}$ & $1874.9^{\mathrm{c}-\mathrm{h}}$ \\
\hline \multirow[t]{3}{*}{$4.23 \mathrm{t} / \mathrm{ha}$} & 2013 & $995.10^{\mathrm{s}-\mathrm{v}}$ & $1492.9^{\mathrm{k}-\mathrm{r}}$ & $2174.0^{\mathrm{a}-\mathrm{d}}$ & $2271.9^{\mathrm{a}}$ \\
\hline & 2014 & $883.10^{\mathrm{u}-\mathrm{y}}$ & $1258.5^{\mathrm{p}-\mathrm{t}}$ & $1566.1^{\mathrm{h}-\mathrm{q}}$ & $1462.1^{\mathrm{k}-\mathrm{r}}$ \\
\hline & 2015 & $648.00^{\mathrm{w}-\mathrm{y}}$ & $1350.5^{\mathrm{m}-\mathrm{r}}$ & $1545.2^{\mathrm{h}-\mathrm{q}}$ & $1928.3^{\mathrm{b}-\mathrm{f}}$ \\
\hline \multirow[t]{3}{*}{$5.64 \mathrm{t} / \mathrm{ha}$} & 2013 & $889.60^{\mathrm{u}-\mathrm{x}}$ & $1642.3^{\mathrm{g}-\mathrm{n}}$ & $2056.7^{\mathrm{a}-\mathrm{e}}$ & $2074.5^{\mathrm{a}-\mathrm{e}}$ \\
\hline & 2014 & $1002.5^{\mathrm{s}-\mathrm{v}}$ & $1314.0^{\mathrm{n}-\mathrm{s}}$ & $1614.4^{\mathrm{g}-\mathrm{o}}$ & $1547.2^{\mathrm{h}-\mathrm{q}}$ \\
\hline & 2015 & $695.00^{v-y}$ & $1296.7^{\mathrm{o}-\mathrm{s}}$ & $1590.1^{\mathrm{h}-\mathrm{p}}$ & $1845.6^{\mathrm{d}-\mathrm{j}}$ \\
\hline Mean & & & 1447.31 & & \\
\hline $\mathrm{CV}$ & & & 13.850 & & \\
\hline LSD & & & 337.11 & & \\
\hline
\end{tabular}

Means with the same letter(s) are statistically not significantly different at 0.05 probability level

Where, $\mathrm{t} / \mathrm{ha}=$ ton per hectare, $\mathrm{LSD}=$ list significant different, $\mathrm{CV}=$ coefficient of variation 


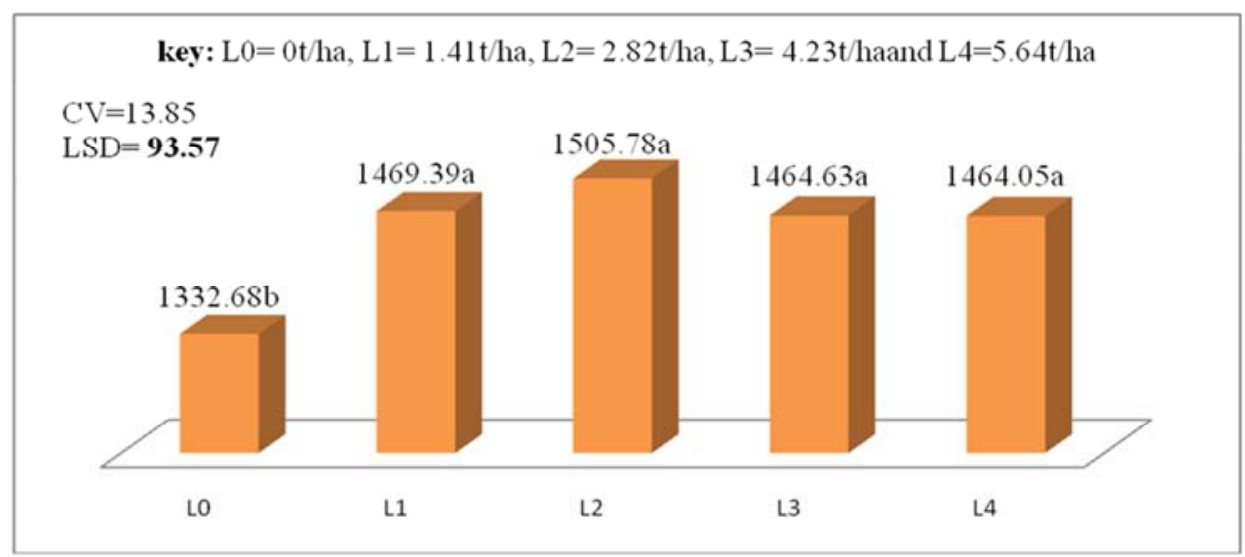

Figure 6. Main effect of lime on soybean mean grain yield $(\mathrm{kg} / \mathrm{ha})$ at Mettu.

Means with the same letter(s) are statistically not significantly different at 0.05 probability level Where, $\mathrm{L}=$ lime, $\mathrm{LSD}=$ list significant different, $\mathrm{CV}=$ coefficient of variation

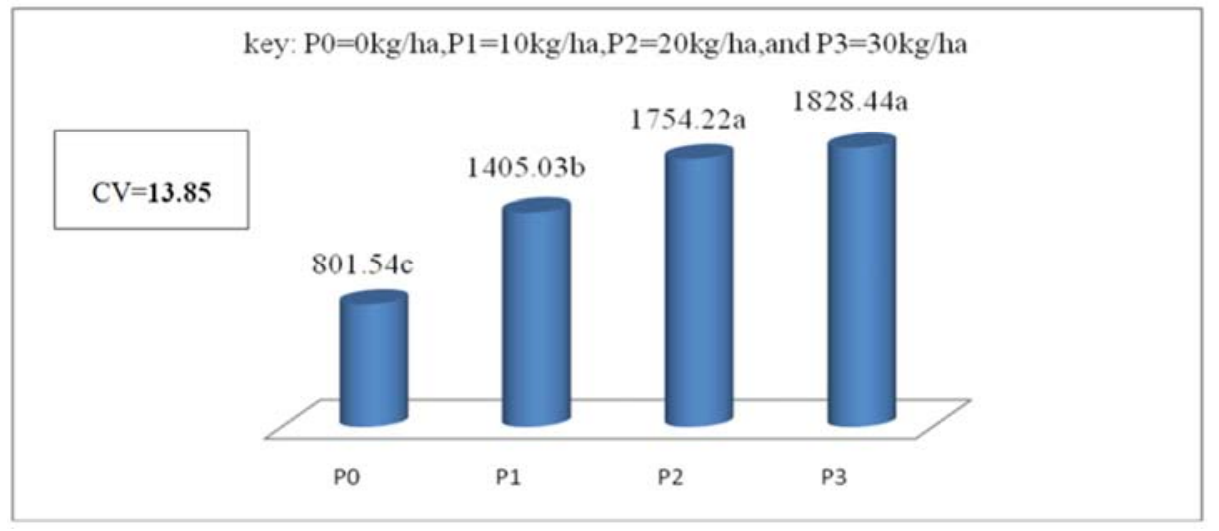

Where, $\mathrm{P}=$ =hosphorus, $\mathrm{LSD}=$ list significant different, $\mathrm{CV}=$ coefficient of variation

Figure 7. Main effect of phosphorus on soybean mean grain yield $(\mathrm{kg} / \mathrm{ha}$ ) at Mettu. Means with the same letter(s) are statistically not significantly different at 0.05 probability level.

Analysis of variance showed that the main effects of lime, season and Phosphorus, and the interaction of phosphorus $\mathrm{x}$ season $\mathrm{x}$ lime had highly significant effect on number of seed per plant (Table 4). The highest number of seed per plant of soybean (77.67) was obtained from plants treated with 4.23t/ha lime $+30 \mathrm{P} \mathrm{kg} / \mathrm{ha}$ whereas the lowest number of seed per plant of soybean (27 and 28) was recorded from both lime and phosphorus untreated plots ( $0 \mathrm{~kg} \mathrm{P} / \mathrm{ha}$ and $0 \mathrm{t} / \mathrm{ha}$ lime).

The positive response of soybean to applied lime and $\mathrm{P}$ might be due to the improvement of soil $\mathrm{pH}$ in response to lime amendment, which enhanced growth and yield of the plant, as a result of increased availability of $\mathrm{P}$ that might have increased intensity of photosynthesis, flowering, seed formation and fruiting. [5] Reported that the beneficial effects of lime with P for legumes grown on acidic soil, in which liming of acid soils significantly increased number of seeds of haricot bean, this may be because of the fact that acidic soil was neutralized by the applied lime.

Table 4. Interaction effects of lime, season and phosphorus on seed per plant of soybean at Mettu.

\begin{tabular}{|c|c|c|c|c|c|}
\hline \multirow{2}{*}{ Lime level } & \multirow{2}{*}{ Year } & \multicolumn{4}{|c|}{ Phosphorus rate (kg/ha) } \\
\hline & & $0 \mathrm{~kg} / \mathrm{ha}$ & $10 \mathrm{~kg} / \mathrm{ha}$ & $20 \mathrm{~kg} / \mathrm{ha}$ & $30 \mathrm{~kg} / \mathrm{ha}$ \\
\hline \multirow[t]{2}{*}{$0 \mathrm{t} / \mathrm{ha}$} & 2013 & $41.33^{\mathrm{k}-\mathrm{o}}$ & $55.33^{\mathrm{c}-\mathrm{k}}$ & $60.67^{\mathrm{b}-\mathrm{i}}$ & $68.67^{\mathrm{a}-\mathrm{c}}$ \\
\hline & 2014 & $28.33^{\text {no }}$ & $49.67^{\mathrm{f}-\mathrm{k}}$ & $56.0^{\mathrm{c}-\mathrm{k}}$ & $63.0^{\mathrm{a}-\mathrm{g}}$ \\
\hline \multirow[t]{2}{*}{$1.41 \mathrm{t} / \mathrm{ha}$} & 2013 & $45.33^{\mathrm{j}-\mathrm{m}}$ & $61.0^{b-\mathrm{i}}$ & $72.67^{\mathrm{ab}}$ & $68.0^{a-d}$ \\
\hline & 2014 & $27.33^{\circ}$ & $49.0^{\mathrm{g}-\mathrm{k}}$ & $68.0^{\mathrm{a}-\mathrm{d}}$ & $66.33^{\mathrm{a}-\mathrm{e}}$ \\
\hline \multirow[t]{2}{*}{$2.82 \mathrm{t} / \mathrm{ha}$} & 2013 & $47.67^{\mathrm{h}-1}$ & $53.67^{\mathrm{d}-\mathrm{k}}$ & $51.33^{\mathrm{f-k}}$ & $59.0^{\mathrm{b-j}}$ \\
\hline & 2014 & $30.67^{\mathrm{m}-\mathrm{o}}$ & $54.33^{\mathrm{c}-\mathrm{k}}$ & $64.0^{\mathrm{a}-\mathrm{f}}$ & $68.33^{\mathrm{a}-\mathrm{d}}$ \\
\hline \multirow[t]{2}{*}{$4.23 \mathrm{t} / \mathrm{ha}$} & 2013 & $47.33^{\mathrm{i}-1}$ & $67.67^{\mathrm{a}-\mathrm{d}}$ & $68.67^{\mathrm{a}-\mathrm{c}}$ & $55.0^{\mathrm{c}-\mathrm{k}}$ \\
\hline & 2014 & $33.67^{1-0}$ & $43.67^{\mathrm{k}-\mathrm{m}}$ & $60.33^{\mathrm{b}-\mathrm{i}}$ & $77.67^{\mathrm{a}}$ \\
\hline $5.64 \mathrm{t} / \mathrm{ha}$ & 2013 & $42.33^{\mathrm{k}-\mathrm{n}}$ & $51.0^{\mathrm{f}-\mathrm{j}}$ & $64.0^{\mathrm{a}-\mathrm{f}}$ & $62.33^{\mathrm{b}-\mathrm{h}}$ \\
\hline
\end{tabular}




\begin{tabular}{|c|c|c|c|c|c|}
\hline \multirow{2}{*}{ Lime level } & \multirow{2}{*}{ Year } & \multicolumn{4}{|c|}{ Phosphorus rate (kg/ha) } \\
\hline & & $0 \mathrm{~kg} / \mathrm{ha}$ & $10 \mathrm{~kg} / \mathrm{ha}$ & $20 \mathrm{~kg} / \mathrm{ha}$ & $30 \mathrm{~kg} / \mathrm{ha}$ \\
\hline & 2014 & $32.0^{\mathrm{m}-\mathrm{o}}$ & $51.67^{\mathrm{e}-\mathrm{k}}$ & $71.33^{\mathrm{ab}}$ & $71.0^{\mathrm{ab}}$ \\
\hline Mean & & $37.6^{\mathrm{c}}$ & $53.7^{\mathrm{b}}$ & $63.7^{\mathrm{a}}$ & $65.93^{\mathrm{a}}$ \\
\hline LSD & & 14.70 & & & \\
\hline $\mathrm{CV}$ & & 16.38 & & & \\
\hline
\end{tabular}

Means with the same letter(s) are statistically not significantly different at 0.05 probability level

Where, $\mathrm{t} / \mathrm{ha}=$ ton per hectare, $\mathrm{LSD}=$ list significant different, $\mathrm{CV}=$ coefficient of variation

\subsection{Influence of Lime and Phosphorus on Soybean Hundred Seed Weight}

Analysis of variance revealed that the main effect of phosphorus and lime application, and interaction effect of phosphorus $\times$ lime had significant influence on seed weight of soybean (Figure 8 ). In this study lime and phosphorus significantly influence seed weight of soybean. A combination of lime and phosphorus fertilizer resulted in higher seed weight than that with lime or $\mathrm{P}$ used independently. The highest hundred seed weigh of soybean (14.3 to 16.7 gram) was obtained from plants treated with both lime rate +20 and $30 \mathrm{P} \mathrm{kg} /$ ha except 0 and $10 \mathrm{P} \mathrm{kg} / \mathrm{ha}$ whereas the lowest hundred seed weight (11.67 to 12.3 gram) was recorded from lowest phosphorus treated and untreated plots ( 0 and $10 \mathrm{P} /$ ha of all lime treated and untreated plots). The combined application of lime with $\mathrm{P}$, and $\mathrm{P}$ alone increased hundred seed weight than lime alone, which might be due to the importance of $\mathrm{P}$ in improving phosphorus nutrition of the crops, and phosphorus plays important role in seed development and increase in seed size. And also due to ability of this treatment to improve $\mathrm{Ca}$ nutrition of the crop. In line with this finding, [23] reported that application of phosphorus at the rate of $30 \mathrm{~kg} / \mathrm{ha}$ increased hundred seed weight of barley by $4.6 \%$ over the control treatment (no phosphorus). Generally in this study there was no more effect of lime than the influence of phosphorus fertilizer on hundred seed weight of soybean.

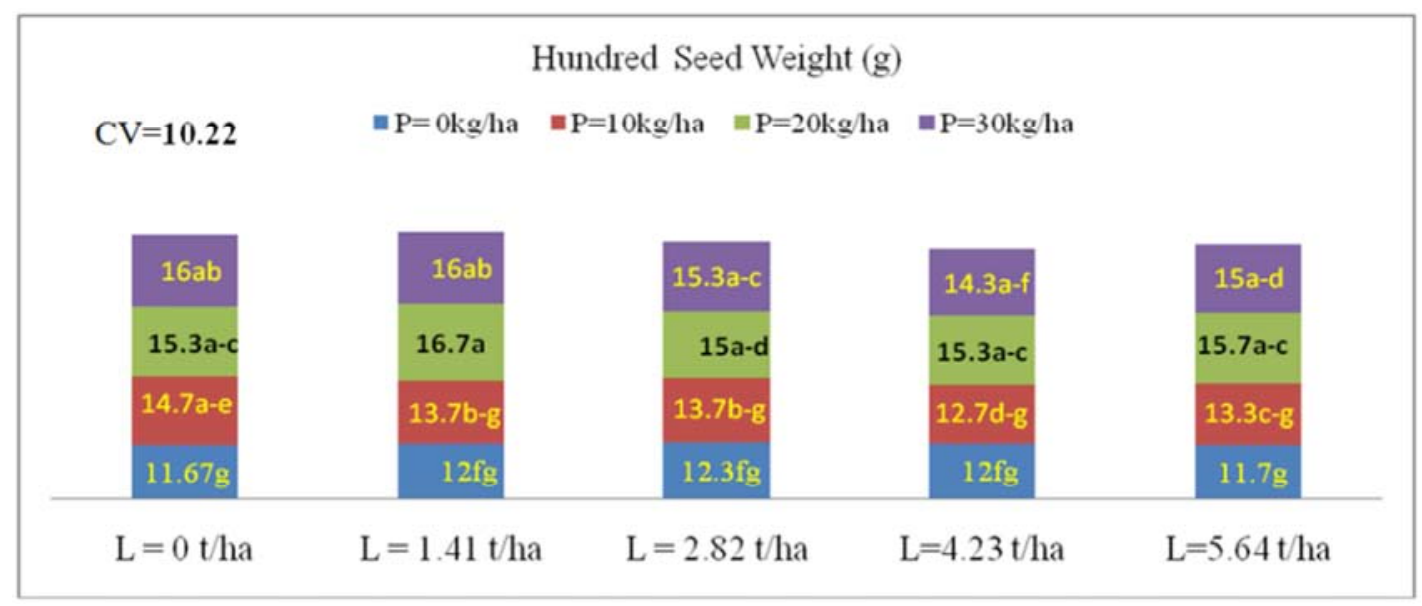

Figure 8. Interaction effect of lime and phosphorus level on hundred seed weight of soybean at Mettu.

Means with the same letter(s) are statistically not significantly different at 0.05 probability level

Where, $\mathrm{L}=$ lime, $\mathrm{t} / \mathrm{ha}=$ ton per hectare $\mathrm{P}=$ phosphorus, $\mathrm{LSD}=$ list significant different, $\mathrm{CV}=$ coefficient of variation.

\subsection{Influence of Lime and Phosphorus Fertilizer on Soybean dry Biomass Weight}

The main effect of lime and phosphorus rates revealed highly significant $(\mathrm{P}<0.01)$ effect on above ground biomass of soybean. Similarly, their interaction showed significant effect on above ground biomass (Table 5). Lime with phosphorus revealed significant effect on above ground biomass (Table 5). The highest biomass $\left(6.25 \mathrm{t} \mathrm{ha}^{-1}\right)$ was recorded from limed at the rate of $1.41 \mathrm{t} / \mathrm{ha}$ with $20 \mathrm{P} \mathrm{kg} / \mathrm{ha}$ whereas the lowest biomass $\left(1.55 \mathrm{t} \mathrm{ha}^{-1}\right)$ was obtained from control plot ( $0 \mathrm{t} / \mathrm{ha}$ lime and $0 \mathrm{P} \mathrm{kg} / \mathrm{ha})$. Lime with phosphorus improved above ground biomass compared to untreated control plots (Table 5).
Phosphorus and liming amendment increased above ground dry biomass which might be due to improved rate of $\mathrm{P}$ supply to the soil or an improved ability of the plant to absorb P, when Al toxicity has been eliminated, and enhanced the vegetative growth of soybean genotypes, which resulted in increased dry biomass. Similarly, the increase in above ground biomass yield with increasing rate of $\mathrm{P}$ may be attributed to the better availability $\mathrm{P}$ for plants as the rate of external $\mathrm{P}$ application increase which in turn observed on better plant performance. The better performance of the crop with liming may be also related with the better nodule development which stimulated effective $\mathrm{N} 2$ fixation, increasing the amount of $\mathrm{N}$ available to support growth. Similar to this finding, [23] reported that the highest dry 
biomass of barley were recorded on lime amended soil with $2.2 \mathrm{t} \mathrm{ha}^{-1}$ and $30 \mathrm{~kg} \mathrm{P} \mathrm{ha}^{-1}$ than separate application of lime and phosphorus.

Table 5. Interaction effects of lime, season and phosphorus on above ground biomass of soybean at Mettu.

\begin{tabular}{|c|c|c|c|c|c|}
\hline \multirow{3}{*}{ Lime rate } & \multicolumn{5}{|c|}{ Above ground dry biomass ton/ha } \\
\hline & \multirow{2}{*}{ Year (GC) } & \multicolumn{4}{|c|}{ Phosphorus level } \\
\hline & & $0 \mathrm{~kg} / \mathrm{ha}$ & $10 \mathrm{~kg} / \mathrm{ha}$ & $20 \mathrm{~kg} / \mathrm{ha}$ & $30 \mathrm{~kg} / \mathrm{ha}$ \\
\hline \multirow[t]{3}{*}{$0 \mathrm{t} / \mathrm{ha}$} & 2013 & $1.61^{\mathrm{w}}$ & $3.37^{\mathrm{p}-\mathrm{s}}$ & $5.31 \mathrm{~b}-\mathrm{f}$ & $4.65^{\mathrm{e}-\mathrm{k}}$ \\
\hline & 2014 & $1.92^{\mathrm{u}-\mathrm{w}}$ & $3.75^{1-q}$ & $4.34 \mathrm{~g}-\mathrm{n}$ & $5.08^{\mathrm{c}-\mathrm{h}}$ \\
\hline & 2015 & $1.55^{\mathrm{w}}$ & $3.52^{\mathrm{n}-\mathrm{r}}$ & $4.31 \mathrm{~g}-\mathrm{n}$ & $5.13^{\mathrm{c}-\mathrm{h}}$ \\
\hline \multirow[t]{3}{*}{$1.41 \mathrm{t} / \mathrm{ha}$} & 2013 & $1.77^{\mathrm{vw}}$ & $4.26^{\mathrm{h}-\mathrm{o}}$ & $6.26^{\mathrm{a}}$ & $5.817^{\mathrm{a}-\mathrm{d}}$ \\
\hline & 2014 & $2.58^{\mathrm{s}-\mathrm{v}}$ & $4.27^{\mathrm{g}-\mathrm{n}}$ & $4.69 \mathrm{e}-\mathrm{j}$ & $4.82^{\mathrm{e}-\mathrm{i}}$ \\
\hline & 2015 & $1.51^{\mathrm{w}}$ & $3.80^{\mathrm{k}-\mathrm{q}}$ & $4.33 \mathrm{~g}-\mathrm{n}$ & $5.42^{\mathrm{a}-\mathrm{f}}$ \\
\hline \multirow[t]{3}{*}{$2.82 \mathrm{t} / \mathrm{ha}$} & 2013 & $3.05^{\mathrm{r}-\mathrm{t}}$ & $3.95^{\mathrm{i}-\mathrm{p}}$ & $5.87^{\mathrm{a}-\mathrm{c}}$ & $5.47^{\mathrm{a}-\mathrm{f}}$ \\
\hline & 2014 & $2.76^{\mathrm{r}-\mathrm{u}}$ & $3.68^{\mathrm{m}-\mathrm{q}}$ & $4.66 \mathrm{e}-\mathrm{k}$ & $5.33^{\mathrm{b}-\mathrm{f}}$ \\
\hline & 2015 & $1.91^{\mathrm{u}-\mathrm{w}}$ & $3.50^{\mathrm{n}-\mathrm{r}}$ & $4.55 \mathrm{f}-\mathrm{m}$ & $5.45^{\mathrm{a}-\mathrm{e}}$ \\
\hline \multirow[t]{3}{*}{$4.23 \mathrm{t} / \mathrm{ha}$} & 2013 & $2.26^{\mathrm{t}-\mathrm{w}}$ & $3.84^{j-q}$ & $5.85^{\mathrm{a}-\mathrm{c}}$ & $6.16^{\mathrm{ab}}$ \\
\hline & 2014 & $2.56^{\mathrm{s}-\mathrm{v}}$ & $3.90^{j-q}$ & $4.62 \mathrm{e}-1$ & $4.97^{\mathrm{d}-\mathrm{h}}$ \\
\hline & 2015 & $1.92^{\mathrm{u}-\mathrm{w}}$ & $3.69^{\mathrm{m}-\mathrm{q}}$ & $4.25 \mathrm{~h}-\mathrm{p}$ & $5.15^{\mathrm{c}-\mathrm{g}}$ \\
\hline \multirow[t]{3}{*}{$5.64 \mathrm{t} / \mathrm{ha}$} & 2013 & $2.59^{\mathrm{s}-\mathrm{v}}$ & $4.01^{\mathrm{i}-\mathrm{p}}$ & $5.32 b-f$ & $5.43^{\mathrm{a}-\mathrm{f}}$ \\
\hline & 2014 & $2.70^{\mathrm{r}-\mathrm{u}}$ & $3.82^{j-q}$ & $4.64 \mathrm{e}-\mathrm{k}$ & $5.25^{\mathrm{c}-\mathrm{f}}$ \\
\hline & 2015 & $2.02^{\mathrm{u}-\mathrm{w}}$ & $3.38^{0-\mathrm{s}}$ & $4.26^{\mathrm{h}-\mathrm{n}}$ & $5.31^{\mathrm{b}-\mathrm{f}}$ \\
\hline Mean & 4.027 & & & & \\
\hline $\mathrm{CV}$ & 13.22 & & & & \\
\hline LSD & 00.87 & & & & \\
\hline
\end{tabular}

Means with the same letter(s) are statistically not significantly different at 0.05 probability level

Where, $\mathrm{t} / \mathrm{ha}=$ ton per hectare, $\mathrm{LSD}=$ list significant different, $\mathrm{CV}=$ coefficient of variation

\section{Conclusion and Recommendations}

The results of this study, clearly demonstrated that these soils are responsive to lime and phosphate fertilizer applications. Overall, results showed that there were significant changes in soil $\mathrm{pH}$ and exchangeable acidity as a result of amendment through liming. Soil chemical properties $(\mathrm{pH})$ were increased, which may be responsible for higher soybean yields. The results of the effects of agricultural limes on soil showed that all plots receiving lime recorded an increase in soil $\mathrm{pH}$. However, lime rate of $5.64 \mathrm{t} \mathrm{ha}^{-1}$ of agricultural limes had increased the soil $\mathrm{pH}$ by 4.82 . Exchangeable acidity was also affected by the applied lime rates. On the other hand, from the $\mathrm{P}$ rates of $30 \mathrm{p} \mathrm{kg} \mathrm{ha}{ }^{-1}$ had gives a higher soybean grain yield. Hence, for sustainable and higher productivity, soybean production in the south western of Ethiopia should entail applications of $4.23 \mathrm{t} \mathrm{ha}^{-1}, 30 \mathrm{~kg} \mathrm{P} \mathrm{ha}^{-1}$, and use of improved high yielding soybean varieties. However, as soils vary from site to site, the amount of lime applied should be based on the concentrations of exchangeable acidity of site. The lime and $\mathrm{P}$ rates obtained in this study could serve as a reference to boost soybean production in the study area and areas with similar agoecology having soil acidity problems. Hence a combined application of phosphorous at $30 \mathrm{~kg} / \mathrm{ha}$ and lime at $5.64 \mathrm{t} \mathrm{ha}^{-1}$ had good response in reclaiming the soil and increasing crop productivity. However, as the data of this study was at one location, over locations data under different soil type in the study area should be included to reach at a conclusive recommendation and to determine the residual effect of phosphorus and lime on the soil and on the crop. Also further study should be conducted to determine the response of different maturity group of soybean varieties to appropriate rates or combination of lime and phosphorus fertilizers which can maximize the productivity of the crop and reduce soil acidity problem in the study area. For the a sound recommendation this study should be conducted across different acid soil and the agricultural extension suggest the farmers as they apply lime based on the concentration of acid saturation cation until the best combination of lime and phosphorus will be determined.

\section{Conflict of Interests}

The authors have not declared any conflict of interests

\section{Acknowledgements}

The authors are grateful to the financial grant of the Ethiopian institute of agricultural research through the Jimma agricultural research center. We also acknowledges Jimma agricultural research center for facilitating the research work and also acknowledge the staff members of Mettu research sub center for their technical assistance during the time of conducting the field experiment and data collection.

\section{References}

[1] Anetor O. \& E. Akinrinde, (2006). Response of soybean [Glycine $\max ($ L.) Merrill] to lime and phosphorus fertilizer treatments on an acidic alfisol of Nigeria. Pakistan Journal of Nutrition, 5, 286-293.

[2] Baruah C. and P. Barthakur, 1997. A Textbook of Soil analysis, Vikas Publishing House, New Delhi, India.

[3] Boyer JS (1982) Plant productivity and environment. Science 218: 443-448.

[4] Brady C. and R. Weil, 2002. The nature and properties of soils, 13th. Pearson education (Singapore) Pte. Ltd. Indian Branch, 482: 621-624.

[5] Chalk M., J. Alves, M. Boddey and S. Urquiaga, 2010. Integrated effects of abiotic stresses on inoculants performance, legume growth and symbiotic dependence estimated by $15 \mathrm{~N}$ dilutions. Plant and Soil, 328: 1-16.

[6] Delhaize E., D. Gruber and R. Ryan, 2007. The roles of organic anion permeases in aluminium resistance and mineral nutrition. Febs Letters, 581: 2255-2262.

[7] Ethiosis., 2014. Soil fertility mapping and fertilizer blending. Agricultural Transformation Agency (ATA) Report, Ethiopia soil information system (Ethiosis). Ministry of Agriculture, Addis Ababa.

[8] Fageria K. and C. Baligar, 2008. Ameliorating soil acidity of tropical Oxisols by liming for sustainable crop production. Advances in agronomy, 99: 345-399. 
[9] Foth HD, Ellis BG (1997) Soil Fertility and Fertilizers. In: Soil Fertility. Pearson Education Inc., Upper Saddle River, CRC Press, Inc. Boca Raton FL.

[10] Kariuki K., H. Zhang, L. Schroder, J. Edwards, M. Payton, F. Carver, R. Raun and G. Krenzer, 2007. Hard red winter wheat cultivar responses to a $\mathrm{pH}$ and aluminum concentration gradient. Agronomy journal, 99: 88-98.

[11] Kariuki K., H. Zhang, L. Schroder, J. Edwards, M. Payton, F. Carver, R. Raun and G. Krenzer, 2007. Hard red winter wheat cultivar responses to a $\mathrm{pH}$ and aluminum concentration gradient. Agronomy journal, 99: 88-98.

[12] Kisinyo O., 2016. Long term effects of lime and phosphorus application on maize productivity in an acid soil of Uasin Gishu County, Kenya. Sky Journal of Agricultural Research, 5: $48-55$.

[13] Kochian V., A. Hoekenga and A. Pineros, 2004. How do crop plants tolerate acid soils? Mechanisms of aluminum tolerance and phosphorous efficiency. Annu. Rev. Plant Biol., 55: 459493.

[14] Kochian V., A. Hoekenga and A. Pineros, 2004. How do crop plants tolerate acid soils? Mechanisms of aluminum tolerance and phosphorous efficiency. Annu. Rev. Plant Biol., 55: 459493.

[15] Maddox JS, Soileux JM (1991) Effects of phosphate fertilizer, lime amendment and inoculation with VA-mychorrhizal fung on soybean in an acid soil. In: Wright et al. (Ed.), Plant and Soil interaction at low pH, pp: 215-225.

[16] Melese A (2014) Soils of farta district, northwestern highlands of Ethiopia. Phd dissertation. Haramaya University, Ethiopia.

[17] Mesfin Kassa, Belay Yebo and Abera Habte. 2014 (b). Liming Effects on Yield and Yield Components of Haricot Bean (Phaseolus vulgaris L.) Varieties Grown in Acidic Soil at Damot Sore District, Southern Ethiopia. Greener Journal of
Plant Breeding and Crop Science, 2 (4): 76-81.

[18] Mesfin A., 2007. Nature and management of acid soils in Ethiopia. Addis Ababa, Ethiopia. 99 p.

[19] SAS (Statistical Analysis System) soft ware, 2012. Version9.3, SAS institute, Cary, NC, USA.

[20] Shahid Q., F. Saleem, Z. Khan and A. Anjum, 2009. Performance of soybean (Glycine max L.) under different phosphorus levels and inoculation. Pakistan Journal of Agricultural Sciences, 46: 237-241.

[21] Shoemaker E., O. Mclean and F. Pratt, 1961. Buffer methods for determing lime requirement of soils with appreciable amounts of extractable aluminum 1. Soil Science Society American. Proceeding, 25: 274-277.

[22] Sumner ME, Noble AD (2003) Soil acLdLficatLon the world story. In: Rengel Z (ed.). Handbook of soil acidity, pp: 1-28.

[23] Temasgen D., G. Alemu, A. Adella and D. Tolessa, 2017. Effect of lime and phosphorus fertilizer on Acid soils and barley (Hordeum vulgare l.) performance in the central highlands of Ethiopia. Experimental Agriculture, 53: 432-444.

[24] Von Uexkull R and E. Mutert, 1995. Global extent, development and economic impact of acid soils. Plant and soil, 171: 1-15.

[25] Wang P., H. Raman, P. Zhang, N. Mendham and X. Zhou, 2006. Aluminium tolerance in barley (Hordeum vulgare L.): physiological mechanisms, genetics and screening methods. Journal of Zhejiang University SCIENCE B, 7: 769-787.

[26] Workneh B., K. Tesfu and D. Jafer, 2013. Growth and Nodulation Response of Soybean (Glycine max L.) to Lime, Bradyrhizobium japonicum and Nitrogen Fertilizer in Acid Soil at Melko, South Western Ethiopia. International Journal of Soil Science, 8: 25-31. 